\title{
The effectiveness of educational interventions in reducing negative attitudes and stigmatisation toward patients with anorexia nervosa
}

Amy Bannatyne*, Peta Stapleton

From 2013 ANZAED Conference: Inspiring Change: Person and Context Melbourne, Australia. 23-24 August 2013

It is frequently reported that clinicians across a range of professional disciplines experience strong negative reactions toward patients with eating disorders, particularly anorexia nervosa (AN). As research consistently demonstrates fear of stigma is the most frequently cited reason explaining why individuals with mental illness do not seek treatment, the current study aimed to develop, evaluate and compare the effectiveness of two differing educational interventions, based on an etiological framing model, against a wait-list control. Participants were fourth-year medicine students randomly assigned to one of three conditions. A three-hour educational workshop was delivered to participants at the beginning of an eight-week clinical rotation. Outcome attitudinal data were collected pre-intervention, post-intervention, and at an eight-week follow-up period. It was hypothesised that both intervention groups would result in more positive attitudes toward AN, compared to the wait-list control, with the biologically-framed intervention resulting in the greatest stigma-reduction effect, consistent with Attribution Theory. Preliminary findings will be discussed.

This abstract was presented in the Prevention stream of the 2013 ANZAED Conference.

Published: 14 November 2013

doi:10.1186/2050-2974-1-S1-038

Cite this article as: Bannatyne and Stapleton: The effectiveness of

educational interventions in reducing negative attitudes and

stigmatisation toward patients with anorexia nervosa. Journal of Eating

Disorders 2013 1(Suppl 1):O38.

* Correspondence: abannaty@bond.edu.au

Bond University, Australia
Submit your next manuscript to BioMed Central and take full advantage of:

- Convenient online submission

- Thorough peer review

- No space constraints or color figure charges

- Immediate publication on acceptance

- Inclusion in PubMed, CAS, Scopus and Google Scholar

- Research which is freely available for redistribution
C Biomed Central 